\title{
KARAKTERISTIK FISIKOKIMIA KERUPUK SABRANG (COLEUS TUBEROSUS) PADA VARIASI PEMBERIAN UMBI SABRANG
}

\section{Physicochemical Characteristic of Crackers Formulated with Sabrang (Coleus tuberosus) in Various Concentration of Sabrang}

\author{
Yuli Kusuma Dewi \\ Program Studi Tadris Kimia, FTK Universitas Islam Negeri Mataram \\ JI. Gadjah Mada No.100, Jempong Baru, Mataram \\ *Penulis Korespondensi, Email: yulichemist@uinmataram.ac.id
}

\begin{abstract}
ABSTRAK
Sabrang (Coleus tuberosus) merupakan umbi lokal Pulau Lombok yang kandungan utamanya adalah karbohidrat/pati namun juga memiliki kandungan protein dan mineral yang cukup tinggi, sehingga dapat dimanfaatkan menjadi bahan pembuatan kerupuk. Penelitian menggunakan formulasi dengan lima varian pemberian sabrang mulai dari konsentrasi $0 \%$ hingga $60 \%$. Tujuan penelitian ini yaitu menentukan formulasi kerupuk sabrang yang menghasilkan karakteristik fisikokimia kerupuk terbaik. Parameter yang dianalisa yaitu kadar air, abu, protein, lemak, karbohidrat, nilai $\mathrm{pH}$ dan daya kembang dari kerupuk sabrang. Berdasarkan hasil penelitian, diketahui bahwa variasi konsentrasi sabrang berpengaruh secara nyata terhadap karakteristik fisikokimia kerupuk. Kadar air, abu, protein, karbohidrat, dan daya kembang kerupuk cenderung meningkat dengan penambahan konsentrasi sabrang hingga batas tertentu, sedangkan untuk nilai $\mathrm{pH}$ dan lemak sebaliknya. Variasi konsentrasi umbi sabrang yang menghasilkan karakteristik fisikokimia terbaik adalah $\mathrm{P}_{2}$ dengan konsentrasi sabrang 30\%. Kerupuk yang dihasilkan memiliki kandungan lemak rendah, protein, mineral yang tinggi serta daya kembang yang baik.
\end{abstract}

Kata kunci: Coleus tuberosus, Fisikokimia, Kerupuk, Sabrang, Variasi konsentrasi

\section{ABSTRACT}

Sabrang (Coleus tuberosus) is local food (root) in Lombok which contains carbohydrates as the main ingredient and high protein and mineral, so that can be used as an ingredient for making crackers. In this study, five variations of sabrang's concentration was used from $0 \%$ to $60 \%$ sabrang for the cracker's formula. The purpose of this research is to determine the cracker's formula which produces the best physicochemical characteristics of sabrang crackers. The parameters tested were water content, ash, protein, fat, carbohydrate, $\mathrm{pH}$ value, and the linear expansion of sabrang crackers. The results show that the water content, ash, protein, and carbohydrate tend to increase with the addition of sabrang concentrations to certain levels, while $\mathrm{pH}$ and fat levels were the opposite. Variations in sabrang's concentration that produce the best physicochemical characteristics is $P_{2}(30 \%)$ with low-fat content, high protein and minerals, and good linear expansion.

Keywords: Coleus tuberosus, Crackers, Physicochemical, Sabrang, Variation concentration

\section{PENDAHULUAN}

Kerupuk adalah salah satu jenis camilan atau snack yang telah dikenal sejak lama oleh masyarakat Indonesia. Makanan ini cukup disukai dan dikenal baik dalam segala usia 
dan tingkat sosial masyarakat. Namun, kerupuk bukan merupakan makanan utama melainkan sebagai makanan pendamping atau camilan pelengkap ketika makan. Oleh karena itu, kerupuk cukup populer di kalangan masyarakat Indonesia dan potensi untuk mengembangkan industri kerupuk cukup besar.

Umumnya kerupuk dibuat dengan tepung terigu atau tepung tapioka sebagai bahan utama, sehingga kandungan gizi yang dimiliki kerupuk terbatas sebagai sumber kalori dari pati. Dari hasil analisa laboratorium, diketahui bahwa kadar protein pada kerupuk mentah beragam mulai dari $0.97 \%$ hingga $11.04 \%$ berat basah, kadar air juga beragam mulai dari $9.91 \%$ hingga $14 \%$, sedangkan kadar pati dimulai dari $10.27 \%$ hingga $26.37 \%$ berat basah (Koswara, 2009). Kandungan nutrisi dalam kerupuk yang terbilang cukup rendah menyebabkan masyarakat berlomba-lomba melakukan inovasi pada kerupuk untuk memperbaiki kualitas gizi pada kerupuk.

Inovasi-inovasi dalam bidang pangan yang terkait dengan kerupuk telah banyak menggunakan bahan tambahan pangan untuk menaikkan kandungan gizi kerupuk. Sebagai contoh yaitu dengan menggunakan udang, ikan, kedelai gandum, dan bahan-bahan pangan lain, dimana penambahan bahan pangan tersebut dapat memengaruhi cita rasa dari kerupuk. Oleh karena itu, peneliti tertarik menggunakan bahan pangan tambahan yang memiliki cita rasa sama dengan bahan utama yakni pati.

Di Lombok terdapat 64 jenis tumbuhan lokal yang umum dimanfaatkan sebagai bahan alternatif pangan. Bagian biji, daun, umbi dan batang dari tumbuhan tersebut dapat dikembangkan untuk memperkuat ketahanan pangan lokal dan nasional. Adapun potensi tumbuhan lokal yang diteliti antara lain, juwet, kepundung, buni, lomak, sabrang, dan ganyong, dimana umbi sabrang mengandung protein dan kalsium yang lebih tinggi daripada umbi yang lain sehingga baik untuk dijadikan camilan atau pengganti nasi (Rohyani, Aryanti, dan Suripto, 2015).

Sabrang (Coleus tuberosus) atau dikenal juga sebagai kentang hitam merupakan tumbuhan sejenis umbi-umbian dengan rasa yang mirip dengan ubi jalar. Umbi ini berpotensi untuk dimanfaatkan sebagai bahan pangan alternatif guna meningkatkan ketahanan pangan nasional dan sebagai bahan pengganti tepung tapioka/tepung terigu dan beras karena kaya akan karbohidrat (Herawati et al., 2018). Akan tetapi, kenyataannya pada masyarakat Pulau Lombok sendiri, umbi tersebut tidak begitu populer sehingga menurunkan nilai ekonomis dari umbi tersebut.

Berdasarkan penelitian Nugraheni, diketahui bahwa sabrang memiliki potensi bioaktif dan antioksidan yakni fenol, flavonoid, asam askorbat dan senyawa asam terpenat (asam ursolat dan asam oleanolik) yang memiliki sifat fungsional terhadap sistem biologis (Nugraheni et al., 2011). Adanya kandungan bioaktif dan antioksidan (terutama pada bagian kulit memiliki kandungan paling tinggi), sabrang memiliki potensi sebagai penurun kolesterol, agen antitumor dan antikanker dan mampu meningkatkan aktivitas enzim antioksidan dalam tubuh seperti superoksida dismutase, katalase, glutathione peroksida (Nugraheni, Santoso, dan Windarwati, 2014).

Berdasarkan uraian diatas, maka peneliti ingin melakukan penelitian yang bertujuan menentukan formulasi kerupuk sabrang agar dapat menghasilkan karakteristik fisikokimia terbaik dengan memanfaatkan sabrang sebagai bahan fortifikasi kerupuk karena memiliki kandungan senyawa yang baik, sekaligus hal tersebut dapat dijadikan upaya untuk mempopulerkan bahan pangan lokal untuk memperkuat kekhasan dan ketahanan pangan lokal di Pulau Lombok. Adapun untuk kerupuk yang dihasilkan harus sesuai dengan standar mutu dari Badan Standardisasi Nasional.

\section{BAHAN DAN METODE}

\section{Bahan}

Bahan-bahan yang digunakan adalah umbi sabrang, bawang putih, bawang merah, garam cap Kapal, lada, minyak goreng merek Bimoli, gula, penyedap rasa merek Masako, 
soda kue $\left(\mathrm{NaHCO}_{3}\right)$ merek Koepoe-koepoe, tepung terigu merek Segitiga biru, tepung tapioka cap Gunung Agung, petroleum benzene (Merck), $\mathrm{H}_{2} \mathrm{SO}_{4}$ (Merck), $\mathrm{K}_{2} \mathrm{SO}_{4}$ (Merck), $\mathrm{CuSO}_{4}$ (Merck), $\mathrm{NaOH}$ (Merck), $\mathrm{H}_{3} \mathrm{BO}_{3}$ (Merck), indikator pp (Merck), bromocresol green (Merck) dan metil merah, etanol (Merck), $\mathrm{HCl}$ (Merck), dan batu didih.

\section{Alat}

Alat-alat yang digunakan adalah loyang, penggiling/blender, pisau, pengaduk, talenan, pemanas/kompor, oven merek Memmert, seperangkat alat gelas merek Pyrex dan Duran, set alat Soxhlet, set Kjehdahl merek Behrotest, mortar/alu, cawan porselen, wajan, saringan/ayakan, panci, timbangan/neraca analitik merek Ohaus, desikator merek Duran, tanur pengabuan merek Thermo Scientific, krus porselen, statif dan klem, dan buret merek Pyrex.

\section{Desain Penelitian}

Penelitian ini terdiri dari 5 variasi konsentrasi umbi sabrang yang digunakan dalam formulasi Kerupuk. Adapun formulasi dari lima variasi konsentrasi kerupuk sabrang tersaji pada Tabel 1.

Tabel 1. Formulasi bahan dalam pengolahan kerupuk Sabrang (Modifikasi Wahyono dan Marzuki, 2010)

\begin{tabular}{lccccc}
\hline \multirow{1}{*}{ Bahan } & \multicolumn{5}{c}{ Formula Kerupuk } \\
\cline { 2 - 6 } & $\mathbf{\mathbf { P } _ { \mathbf { 0 } }}$ & $\mathbf{\mathbf { P } _ { \mathbf { 1 } }}$ & $\mathbf{\mathbf { P } _ { \mathbf { 2 } }}$ & $\mathbf{\mathbf { P } _ { \mathbf { 3 } }}$ & $\mathbf{P}_{\mathbf{4}}$ \\
& $\mathbf{( 0 \% )}$ & $\mathbf{( 1 5 \% )}$ & $\mathbf{( 3 0 \% )}$ & $\mathbf{( 4 5 \% )}$ & $\mathbf{( 6 0 \% )}$ \\
\hline Sabrang (g) & 0 & 150 & 300 & 450 & 600 \\
Tepung Tapioka (g) & 1000 & 850 & 700 & 550 & 400 \\
Tepung Terigu (g) & 100 & 100 & 100 & 100 & 100 \\
Garam (g) & 25 & 25 & 25 & 25 & 25 \\
Telur ayam (g) & 120 & 120 & 120 & 120 & 120 \\
Gula (g) & 20 & 20 & 20 & 20 & 20 \\
Bawang Putih (g) & 30 & 30 & 30 & 30 & 30 \\
Soda Kue (g) & 10 & 10 & 10 & 10 & 10 \\
Penyedap (g) & 15 & 15 & 15 & 15 & 15 \\
Air (ml) & 500 & 500 & 500 & 500 & 500 \\
\hline
\end{tabular}

\section{Metode penelitian}

\section{Pembuatan Kerupuk Sabrang}

Pembuatan adonan kerupuk dimulai dengan melakukan sortasi umbi sabrang, selanjutnya dilakukan pencucian dan blanching uap selama 10 menit, untuk menon-aktifkan enzim-enzim yang terdapat dalam bahan pangan. Tahap selanjutnya umbi dihaluskan dan dicampur dengan bahan-bahan antara lain tepung terigu, tapioka, garam, gula, bawang putih, penguat rasa dan soda kue yang merujuk pada variasi formula kerupuk pada Tabel 1. Kemudian adonan diaduk hingga homogen dilanjutkan dengan dilakukan pencetakan adonan, pengukusan, pendinginan selama 24 jam, pemotongan, pengeringan dan penggorengan.

\section{Karakterisasi Kerupuk Sabrang}

Pengujian karakteristik kimia dari kerupuk sabrang dilakukan analisis proksimat yang merujuk pada metode AOAC (1990) yang meliputi pengujian terhadap kadar air dengan metode Thermogravimetri, kadar abu dengan metode pengeringan, kadar protein dengan metode Kjehdahl, kadar lemak dengan metode Soxhlet, kadar karbohidrat dengan metode by difference. Sedangkan untuk pengujian karakteristik fisik kerupuk sabrang meliputi uji pH dengan $\mathrm{pH}$ meter digital dan uji daya pengembangan kerupuk (persen daya pengembangan linier). 


\section{Metode Analisis Data}

Rancangan penelitiian yang digunakan yaitu Rancangan Acak Lengkap (RAL) nonfaktorial dengan ulangan sebanyak tiga ulangan. Data diuji dengan One Way Anova pada taraf signifikansi $(\alpha)=0.05$, dan dilanjutkan dengan Uji lanjut BNJ jika hasil berbeda secara signifikan (nyata).

\section{HASIL DAN PEMBAHASAN}

\section{Hasil Uji Fisikokimia Kerupuk Sabrang}

Adapun data hasil pengamatan terhadap karakteristik fisikokimia kerupuk sabrang yang telah dibuat sesuai dengan formulasi dapat dilihat pada Tabel 1, berikut.

Tabel 2. Rerata hasil pengamatan karakteristik fisikokimia kerupuk Sabrang

\begin{tabular}{|c|c|c|c|c|c|}
\hline \multirow[b]{2}{*}{ Parameter } & \multicolumn{5}{|c|}{ Variasi Konsentrasi Umbi Sabrang } \\
\hline & $\begin{array}{r}P_{0} \\
(0 \%)\end{array}$ & $\begin{array}{c}P_{1} \\
(15 \%)\end{array}$ & $\begin{array}{c}P_{2} \\
(30 \%)\end{array}$ & $\begin{array}{c}P_{3} \\
(45 \%)\end{array}$ & $\begin{array}{c}P_{4} \\
(60 \%)\end{array}$ \\
\hline Kadar Air (\%) & $2.45^{a}$ & $3.53^{b}$ & $5.13^{\mathrm{e}}$ & $4.77^{d}$ & $4.41^{\mathrm{c}}$ \\
\hline Kadar Abu (\%) & $1.40^{\mathrm{a}}$ & $1.52^{\mathrm{b}}$ & $2.65^{\mathrm{c}}$ & $2.74^{d}$ & $3.93^{\mathrm{e}}$ \\
\hline Kadar Protein (\%) & $0.69^{a}$ & $1.70^{\mathrm{b}}$ & $2.75^{\mathrm{c}}$ & $3.09^{d}$ & $3.79^{\mathrm{e}}$ \\
\hline Kadar Lemak (\%) & $37.06^{d}$ & $25.59^{c}$ & $24.28^{b}$ & $23.28^{a}$ & $22.86^{\mathrm{a}}$ \\
\hline $\begin{array}{l}\text { Kadar Karbohidrat } \\
(\%)\end{array}$ & $58.36^{a}$ & $67.75^{d}$ & $67.24^{d}$ & $63.90^{\mathrm{b}}$ & $64.98^{c}$ \\
\hline Nilai pH & $9.04^{c}$ & $8.77^{b c}$ & $8.34^{\mathrm{b}}$ & $7.46^{\mathrm{a}}$ & $7.39^{a}$ \\
\hline \% Daya Kembang & $56.3^{\mathrm{b}}$ & $80.4^{\mathrm{e}}$ & $74.3^{d}$ & $70.6^{c}$ & $47.2^{\mathrm{a}}$ \\
\hline
\end{tabular}

Data pada tabel diatas memperlihatkan bahwa variasi konsentrasi sabrang akan memengaruhi karakteristik fisikokimia dari kerupuk sabrang, dengan kecenderungan persentase akan meningkat seiring dengan meningkatnya konsentrasi sabrang dalam bahan kerupuk. Namun, untuk beberapa parameter seperti nilai $\mathrm{pH}$, kadar lemak, dan daya kembang terjadi penurunan pada konsentrasi sabrang yang semakin tinggi.

\section{Hubungan Konsentrasi Sabrang Dengan Kadar Air}

Kadar air dalam bahan pangan akan memengaruhi sifat fisik, kimia, perubahan enzimatis, kesegaran, daya tahan, dan turut menentukan penerimaan konsumen (Sholiha dan Palupi, 2016). Semakin tinggi kadar air dalam suatu bahan pangan akan menurunkan daya simpan bahan tersebut (Mustaniroh, Tarigan, dan Maligan, 2020). Kadar air yang tinggi pada kerupuk dapat memengaruhi tekstur sehingga kerupuk menjadi lembek dan tidak mudah patah (Wahyuni, Rais, dan Fadilah 2018). Pada Gambar 1. menunjukkan bahwa kadar air kerupuk sabrang meningkat seiring penambahan konsentrasi sabrang dengan nilai kadar air tertinggi pada $\mathrm{P}_{2}$ yakni sebesar $5.13 \%$. Namun, terjadi sedikit penurunan nilai pada $\mathrm{P}_{3}$ dan $\mathrm{P}_{4}$ yakni $4.77 \%$ dan $4.41 \%$.

Penurunan persentase kadar air pada $\mathrm{P}_{3}$ dan $\mathrm{P}_{4}$ diakibatkan karena pada konsentrasi umbi sabrang $45 \%$ dan $60 \%$, kandungan pati pada kerupuk sabrang relatif lebih sedikit dibandingkan dengan umbi sabrang, sehingga pengikatan molekul air pada pati juga akan berkurang. Pada penelitian hasil kadar air pada semua variasi konsentrasi umbi sabrang yang dihasilkan masih sesuai dengan mutu kerupuk menurut SNI yakni kadar air maksimal untuk kerupuk sebesar 12\%. Sehingga dapat disimpulkan bahwa kerupuk dengan konsentrasi $30 \%\left(\mathrm{P}_{2}\right)$ merupakan formula terbaik dikarenakan kandungan air yang memadai 
akan memengaruhi proses pengembangan kerupuk, karena daya kembang kerupuk dipengaruhi oleh tekanan uap yang mendorong gel pati (Wahyuningtyas, Basito, dan Atmaka, 2014).

\section{Hubungan Konsentrasi Sabrang Dengan Kadar Abu}

Komposisi di dalam bahan pangan terkandung sekitar $96 \%$ bahan organik dan air, sedangkan sisanya adalah unsur-unsur mineral. Mineral juga disebut sebagai zat anorganik atau kadar abu (Swastawati et al., 2013). Kadar abu dalam suatu bahan pangan menunjukkan kandungan mineral yang terdapat dalam suatu bahan pangan. Jika nilai kadar abu tinggi, maka jumlah mineral dari segi nutrisi dalam bahan tersebut juga tinggi (Kusumaningrum dan Asikin, 2016).

Berdasarkan data pada Tabel 2, terlihat bahwa persentase kadar abu pada kerupuk sabrang meningkat seiring dengan peningkatan konsentrasi sabrang. Nilai kadar abu tertinggi pada konsentrasi sabrang $\mathrm{P}_{4}(60 \%)$ sebesar $3.93 \%$ dan terendah pada kerupuk tanpa sabrang $\left(\mathrm{P}_{0}\right)$ sebesar $1.40 \%$. Adapun data kadar abu yang dihasilkan melebihi standar pada SNI yaitu $1 \%$ untuk kerupuk beras. Data tersebut menunjukkan bahwa penambahan umbi sabrang menambah kandungan mineral dalam kerupuk, karena di dalam umbi sabrang terdapat mineral yang cukup tinggi seperti kalsium, besi dan fosfor (Cicilia et al., 2018).

\section{Hubungan Konsentrasi Sabrang Dengan Kadar Protein}

Berdasarkan Tabel 2, nilai kadar protein terendah terdapat pada kerupuk kontrol $\mathrm{P}_{0}$ yakni sebesar $0.69 \%$ dan nilai tertinggi didapatkan pada $\mathrm{P}_{4}(60 \%)$ sebesar $3.79 \%$. Peningkatan kadar protein pada penambahan konsentrasi sabrang menunjukkan bahwa dalam umbi sabrang terdapat kandungan protein yang cukup tinggi, namun cukup rendah apabila dibandingkan dengan penambahan fortifikasi pangan menggunakan daging ikan, daging udang, dan beberapa jenis daging lainnya. Menurut standar mutu kerupuk pasar yang beredar, nilai kadar protein berkisar antara $0.97-11.04 \%$. Sehingga, nilai kadar protein pada kerupuk sabrang untuk semua variasi konsentrasi masih sesuai dengan standar mutu kerupuk.

Keberadaan protein dalam pangan berupa kerupuk sangat penting selain sebagai sumber gizi, protein juga dapat memengaruhi daya kembang kerupuk. Protein dapat terikat sebagai matriks dengan butiran pati yang akan mempengruhi proses gelatinisasi pati. Kandungan protein yang terlalu tinggi akan mengurangi pengembangan kerupuk (Perdani, Amaludin, dan Wijana, 2019). Sehingga, kerupuk $\mathrm{P}_{2}$ dengan kandungan protein menengah dibandingkan variasi konsentrasi yang lain dianggap sebagai konsentrasi terbaik untuk kandungan protein dalam kerupuk sabrang

\section{Hubungan Konsentrasi Sabrang Dengan Kadar Lemak}

Berdasarkan Tabel 2, nilai kadar lemak yang paling tinggi diperoleh pada kerupuk kontrol $\mathrm{P}_{0}$ sebesar $37.06 \%$ dan terendah pada $\mathrm{P}_{4}$ sebesar $22.86 \%$. Kadar lemak yang terukur tersebut adalah lemak dari kerupuk setelah digoreng, sehingga hasil yang diperoleh lebih tinggi daripada nilai rujukan kerupuk mentah yang umumnya berkisar $1.40 \%-12.10 \%$. Hal ini dikarenakan, kerupuk menyerap minyak ketika digoreng. Kerupuk yang digoreng dengan pasir memiliki kadar lemak yang jauh lebih sedikit dibandingkan dengan yang digoreng menggunakan minyak (Dewandari, Basito, dan Anam, 2014).

Penurunan kadar lemak dengan seiring peningkatan konsentrasi sabrang menunjukkan bahwa umbi sabrang mengandung lemak yang tidak tinggi. Hal ini disebabkan, seiring dengan penggantian tepung tapioka oleh umbi sabrang kadar lemak pada kerupuk semakin menurun. Kadar lemak pada bahan pangan yang terlalu tinggi tidak baik disebabkan dapat menyebabkan terjadinya ketengikan pada bahan makanan dan berpengaruh negatif terhadap kesehatan. Oleh karena itu, variasi konsentrasi $\mathrm{P}_{3}$ dan $\mathrm{P}_{4}$ (tidak berbeda secara signifikan) merupakan formula terbaik untuk menghasilkan kadar lemak yang rendah pada kerupuk. 


\section{Hubungan Konsentrasi Sabrang Dengan Kadar Karbohidrat}

Data pada Tabel 1, menunjukkan bahwa kadar karbohidrat meningkat dari perlakuan awal $P_{0}$ hingga $P_{3}$, dan menurun pada perlakuan selanjutnya. Penambahan konsentrasi sabrang juga turut menyebabkan kenaikan dari kadar karbohidrat dari kerupuk sabrang. Hal ini diakibatkan karena umbi sabrang merupakan umbi-umbian dengan kandungan pati yang tinggi. Kadar karbohidrat terendah ada pada perlakuan $\mathrm{P}_{0}(0 \%)$ yakni sebesar $58.36 \%$ dan yang tertinggi pada perlakuan $\mathrm{P}_{1}(15 \%)$ yakni sebesar $67.75 \%$. Namun, secara statistik kadar karbohidrat $\mathrm{P}_{1}$ dan $\mathrm{P}_{2}$ tidak berbeda secara signifikan.

\section{Hubungan Konsentrasi Sabrang Dengan Nilai pH}

$\mathrm{pH}$ merupakan derajat keasaman suatu bahan. Nilai pH dapat dijadikan sebagai salah satu parameter mutu dari suatu kerupuk karena tubuh manusia rata-rata mengandung $80 \%$ basa dan 20\% asam (Amin, 2016). Sehingga, untuk mempertahankan keseimbangan dalam tubuh, makanan yang dikonsumsi sebaiknya merupakan bahan yang tidak memiliki kapasitas asam yang tinggi.

Data pada Tabel 2, menunjukkan penurunan $\mathrm{pH}$ secara bertahap terjadi dengan peningkatan konsentrasi sabrang, namun nilai $\mathrm{pH}$ pada semua variasi konsentrasi sabrang masih diatas 7 dengan nilai $\mathrm{pH}$ terendah 7.39. Nilai tersebut merupakan nilai yang menggambarkan sifat basa pada bahan makanan.

\section{Hubungan Konsentrasi Sabrang Dengan Daya Kembang Kerupuk}

Daya kembang kerupuk merupakan salah satu faktor untuk melihat kualitas kerupuk. Semakin baik daya kembang kerupuk, maka semakin baik tingkat kerenyahan dari suatu kerupuk. Pengembangan kerupuk terjadi diakibatkan adanya proses ekspansi dari uap air. Peristiwa ini terjadi karena adanya tekanan uap yang terbentuk pada saat penggorengan kerupuk (Chaniago, Lamusu, dan Samaduri, 2019). Kandungan air pada kerupuk saat dipanaskan akan mendesak struktur kerupuk yang menyebabkan terjadinya pengembangan secara mendadak. Adapun mekanisme pengembangan kerupuk diawali oleh lepasnya molekul air yang terikat pada gel pati (tepung tapioka) ketika penggorengan. Molekul air yang menguap tersebut mendesak gel-gel pati dalam kerupuk untuk keluar secara serentak, yang mengakibatkan terjadinya pengosongan dan membentuk kantong/gelembung udara pada kerupuk (Koswara, 2009). Semakin tinggi kandungan pati pada kerupuk, maka pembentukan kantung-kantung udara akan semakin banyak. Adanya kandungan air dalam bahan kerupuk disebabkan karena proses gelatinisasi pati. Gelatinisasi adalah proses pembengkakan granula pati yang menyebabkan molekul air menyusup pada bagian pati dan akan membentuk ikatan dengan pati.

Berdasarkan data pada Tabel 2, terlihat bahwa daya kembang kerupuk semakin menurun pada konsentrasi sabrang yang semakin tinggi. Nilai daya kembang terbaik sebesar $80.4 \%$ pada kerupuk $P_{1}(15 \%)$ dan terendah pada $P_{4}$ sebesar $47.2 \%$. Hal ini dikarenakan ketika konsentrasi sabrang bertambah, maka konsentrasi tepung tapiokanya akan dikurangi. Semakin banyaknya penambahan bahan bukan pati menyebabkan penurunan daya kembang kerupuk (Nur, Devi, dan Hidayati, 2017). Semakin tinggi konsentrasi sabrang, menyebabkan proses gelatinisasi pati tidak maksimal dikarenakan kandungan pati yang berkurang, sehingga rongga udara yang dihasilkan pada kerupuk saat penggorengan juga sedikit (Kusuma, Suseno, dan Surjoseputro, 2013). Sehingga dapat disimpulkan bahwa variasi konsentrasi yang menghasilkan pengembangan terbaik adalah $P_{1}$ dan $P_{2}$, sedangkan $\mathrm{P}_{4}$ dan $\mathrm{P}_{0}$ menghasilkan daya kembang kerupuk yang kurang maksimal.

\section{SIMPULAN}

Perlakuan variasi konsentrasi sabrang pada kerupuk berpengaruh secara signifikan (berbeda nyata) terhadap karakteristik fisikokimia kerupuk yakni daya kembang, $\mathrm{pH}$, kadar 
air, kadar abu, kadar protein, kadar lemak, dan kadar karbohidrat. Penambahan konsentrasi umbi sabrang akan meningkatkan nilai kadar karbohidrat, abu, protein dan akan menurunkan kadar lemak dan daya kembang kerupuk. Sehingga, variasi konsentrasi penambahan umbi sabrang terbaik yang menghasilkan karakteristik fisikokimia kerupuk dengan kadar karbohidrat dan lemak yang tidak terlalu tinggi namun memiliki kadar protein serta kadar air yang memadai adalah kerupuk perlakuan $\mathrm{P}_{2}$ dengan formulasi konsentrasi sabrang sebesar $30 \%$.

\section{UCAPAN TERIMA KASIH}

Penulis menyampaikan terimakasih kepada LP2M UIN Mataram yang telah memberikan kesempatan dan sumbangsih dana pada peneliti untuk melakukan penelitian hibah dana kompetitif tahun anggaran 2019.

\section{DAFTAR PUSTAKA}

Amin, S. S. (2016). Optimasi Penggunaan Soda Kue (NaHCO3) Pada Komposisi Kimia, Sifat Fisik dan Organoleptik Kerupuk Puli Beras (Oryza sativa) Jenis C4. UIN Walisongo.

AOAC. (1990). Official Methods of Analysis (15th editi; K. Helrich, Ed.). Washington, D.C.: Association of Official Analytical Chemist, INC.

Chaniago, R., Lamusu, D., \& Samaduri, L. (2019). Kombinasi Tepung Terigu dan Tepung Tapioka Terhadap Daya Kembang dan Sifat Organoleptik Kerupuk Terubuk (Saccharum edule Hasskarl). Jurnal Pengolahan Pangan, 4(1), 1-8. https://doi.org/10.31970/pangan.v4i1.20

Cicilia, S., Basuki, E., Prarudiyanto, A., Alamsyah, A., \& Handito, D. (2018). Pengaruh Substitusi Tepung terigu Dengan Tepung Kentang Hitam (Coleus tuberosus) Terhadap Sifat Kimia dan Organoleptik Cookies. Jurnal IImu Dan Teknologi Pangan, 4(1), 304310.

Dewandari, D., Basito, \& Anam, C. (2014). Kajian Penggunaan Tepung Ubi Jalar Ungu (Ipomoea batatas L.) Terhadap Karakteristik Sensoris dan Fisikokimia Pada Pembuatan Kerupuk. Jurnal Teknosains Pangan, 3(1), 35-52.

Herawati, E. R. N., Ariani, D., Miftakhussolikhah, N., Laila, F., \& Pranoto, Y. (2018). Karakteristik Sohun Pati Aren-Kentang hitam Dengan Penambahan Ekstrak Umbi Bit, daun Suji, dan Kunyit. Jurnal Penelitian Pascapanen Pertanian, 15(3), 122. https://doi.org/10.21082/jpasca.v15n3.2018.147-155

Koswara, S. (2009). Pengolahan Aneka Kerupuk. Retrieved September 22, 2019, from http://tekpan.unimus.ac.id/wp-content/uploads/2013/07/PENGOLAHAN-ANEKA-K-E-RU-P-U-K.pdf

Kusuma, T. D., Suseno, T. I. P., \& Surjoseputro, S. (2013). Pengaruh Proporsi Tapioka dan Terigu Terhadap Sifat Fisikokimia dan Organoleptik Kerupuk Berseledri. Jurnal Teknologi Pangan Dan Giz, 12(1), 17-28.

Kusumaningrum, I., \& Asikin, A. N. (2016). Karakteristik kerupuk Ikan Fortifikasi Kalsium Dari Tulang Ikan Belida. JPHPI, 19(3), 233-240.

Mustaniroh, S. A., Tarigan, I. F., \& Maligan, J. M. (2020). Perbaikan Kualitas Proses Produksi Di UKM Keripik Singkong Kabupaten Malang. Jurnal Pangan Dan Agroindustri, 8(1), 13-18. https://doi.org/10.21776/ub.jpa.2020.008.01.2

Nugraheni, M., Santoso, U., Suparmo, \& Wuryastuti, H. (2011). Potential Of Coleus tuberosus as An Antioxidant and Cancer Chemoprevention Agent. International Food Research Journal, 18(4), 1471-1480.

Nugraheni, Mutiara, Santoso, U., \& Windarwati. (2014). Effect of Consumption of Coleus tuberosus on the Lipid Profile of Alloxan-induced Diabetic Rats. Advance Journal of Food Science and Technology, 6(2), 159-166. 
Nur, A. A. K., Devi, M., \& Hidayati, L. (2017). Pengaruh Penambahan Pegagan (Cantela asiatica L. Urban Terhadap daya Terima dan Mutu Kerupuk. Jurnal Aplikasi Teknologi Pangan, 6(3). https://doi.org/10.17728/jatp.238

Perdani, C. G., Amaludin, F. N., \& Wijana, S. (2019). Formulasi Kerupuk Kentang Granola (Solanum tuberosum L.) Sebagai Makanan Kuliner Khas Tengger Jawa Timur. Jurnal Pangan Dan Agroindustri, 7(3), 37-48. https://doi.org/10.21776/ub.jpa.2019.007.03.5

Rohyani, I. S., Aryanti, E., \& Suripto, S. (2015). Potensi Nilai Gizi Tumbuhan Pangan Lokal Pulau Lombok Sebagai Basis Penguatan Ketahanan Pangan Nasional. Jurnal Sains Teknologi \& Lingkungan, 1(1), 43-47. https://doi.org/10.29303/jstl.v1i1.12

Sholiha, Q., \& Palupi, H. T. (2016). PENGARUH PENAMBAHAN EKSTRAK LIDAH BUAYA (Aloe vera) PADA PEMBUATAN KERUPUK. Teknologi Pangan : Media Informasi Dan Komunikasi IImiah Teknologi Pertanian, 7(1), 29-38. https://doi.org/10.35891/tp.v7i1.502

Swastawati, F., Surti, T., Agustini, T. W., \& Riyadi, P. H. (2013). Karakteristik Kualitas Ikan Asap yang Diproses Menggunakan Metode dan Jenis Ikan Berbeda. Jurnal Aplikasi Teknologi Pangan, 2(3), 126-132.

Wahyono, R., \& Marzuki. (2010). Pembuatan Aneka Kerupuk. Jakarta: Penebar Swadaya.

Wahyuni, S., Rais, M., \& Fadilah, R. (2018). Fortifikasi Tepung Kulit Melinjo Sebagai pewarna Alami Pada Pembuatan Kerupuk Singkong. Jurnal Pendidikan Teknologi Pertanian, 3(2), 212. https://doi.org/10.26858/jptp.v3i2.5710

Wahyuningtyas, N., Basito, \& Windi Atmaka. (2014). Kajian Karakteristik Fisikokimia dan Sensoris Kerupuk Berbahan Baku Tepung Terigu, Tepung Tapioka dan Tepung Pisang Kepok Kuning. Jurnal Teknosains Pangan, 3(2), 76-85. 
